\title{
Possibilities of Weed Beet (Beta vulgaris, L. ssp. marritima) Regulation
}

\author{
Roman Hnilicka - Josef Pulkrabek - Katerina Pazderu \\ Czech University of Life Sciences, Faculty of Agrobiology, Food and Natural Resources, \\ Department of Crop Production, 16521 Praha 6 - Suchdol, Czech Republic \\ hnilickar@af.czu.cz
}

Keywords: sugar beet, TGW, germination, Roundup, Fazor, biological value of seed

\section{SUMMARY}

Weed infestation regulation in sugar beet belongs to the most difficult growing measures, the aim of our work was to find out, if active substances contained in preparations Roundup and Fazor influence number, weight and germination of clusters in plants of weed beets. Statistically significant differences in germinability were found among control and all variants in which preparation Fazor was applied. The Roundup treatment did not have significant influence on germination. Presented results are only preliminary and one-year results, more experiments are necessary to determine the effects of the studied applications.

\section{INTRODUCTION}

Weed infestation regulation in sugar beet belongs to the most difficult growing measures (Jursík, 2010). Due to their close relation with culture plants of beets, the weed beet types are tolerant to the same herbicides used in stands. Composition of weed community in fields is determined by soil conditions, climate, cultivated crop and other agrotechnical measures (Tyšer, 2009). Presence of weed beet in culture stands of sugar beet causes growers severe difficulties. Traditionally, the only effective method to inhibit weed beet is manual weeding (Sester et al., 2006).

To suppress weeds in sugar beet stands, it is usually sufficient to apply three post-emergent herbicides. This strategy is not efficient against weed beet infestation. In the CR, almost half of the areas suitable for sugar beet growing are infested with weed beet. If weed beet is present in the stand, it is necessary to remove it completely. The best method is a mechanical pulling out before the onset of anthesis. The pulled out weed beet must be carried out from the stand or at least put on top of other beets, so it is not in contact with the soil surface (Fišer, 2009). In cases of massive infestation, when manual pulling out cannot be used, we must use e.g. a wick applicator (Rotowiper) or cutting of emerged plants of weed beets. An average plant of weed beet produces about 1,500 seeds; weed beet with earlier anthesis produces more seeds; weed beet with later anthesis produces less seeds. If the weed beet seed is put into the soil, it becomes dormant and can survive in soil for 10 up to 15 years, while the population of germinated seeds decreases by about $50 \%$ (Krouský, 2001). Number of seeds per plant decreases with the density of weed beets, but seed production per area unit increases up to more than $50,000 \mathrm{seeds} / \mathrm{m} 2$ (Sester et al., 2004).

We tried in our model experiment to map seed clusters distribution in the plant of weed beet and to create a plant map with average germination of seed clusters. We also tried with use of two selected substances to influence seed clusters properties: TSW - thousand seeds weight, number of clusters, distribution of clusters numbers in individual size fractions and clusters germination. We monitored influence of morphoregulator Fazor with active substance maleinhydrazin, which inhibits growth and germination. Second preparation was herbicide Roundup with active substance glyphosate.

\section{METHODOLOGY}

Plant maps were worked up for the two plants of weed beets of approximately the same habitus and in the same phenological phase. The results, which will be presented, are their average. These plants were divided to 10 $\mathrm{cm}$ fragments. From these fragments we collected all seed clusters and mix them. In one half of the clusters we measured dry matter content and in the second half of the clusters we measured its germination. Height of the plant was $110 \mathrm{~cm}$.

The aim of our work was to find out, if active substances contained in preparations Roundup and Fazor influence number, weight and germination of clusters in plants of weed beets.

Preparation Fazor was applied in five different concentrations (Table 1). Application term was selected at $\mathrm{BBCH} 72$, which corresponds with beginning of seed formation. Only in preparation dose of $5+5 \mathrm{~g}$ the first dose was analogous with term of others and the second dose was at BBCH 73. Roundup application was selected in the term of $\mathrm{BBCH} 82$, when seeds of weed beets are maturing and the plants have sufficient height, so wick applicator can be used. Thus treated plants matured and were harvested. The plants were left to dry up and to go through period of dormancy. For our experiment we used from each variant 5 plants and make an average from the results. 
Amount and Term of Applied Substances, Dose per 11 of Water

\begin{tabular}{|l|l|}
\hline \multicolumn{2}{|c|}{ Fazor } \\
\hline Dose & Term \\
\hline $1 \mathrm{~g}$ & BBCH 72 \\
\hline $3 \mathrm{~g}$ & BBCH 72 \\
\hline $5 \mathrm{~g}$ & BBCH 72 \\
\hline $5+5 \mathrm{~g}$ & BBCH 72+73 \\
\hline $50 \mathrm{~g}$ & BBCH 72 \\
\hline \multicolumn{2}{|c|}{ Roundup } \\
\hline \multicolumn{2}{|c|}{ BBCH 82} \\
\hline
\end{tabular}

Seed clusters from individual plants were collected in spring and assorted according to size fractions. The first fraction contained clusters of size of $3-4 \mathrm{~mm}$, the second fraction contained clusters of size above $4.5 \mathrm{~mm}$. From each size fraction we collected sample with number of 4 x 50 clusters. Germination of these samples was tested. Temperature in air-conditioned boxes was $20^{\circ} \mathrm{C}$, moisture $60 \%$ and germination proceeded in darkness. Germination test and evaluation of clusters germination was performed after 14 days by ISTA rules. The results were evaluated by multiple-factor analysis ANOVA.

\section{RESULTS AND DISCUSSION}

We found 1344 of seed clusters at the whole plant. Germination and dry matter content of individual seed clusters at the plant shows Picture 1. Germination is expressed as numerator and dry matter content as denominator of fraction. There is also showed, which clusters from different plant parts had the highest germination. There are 6 ten centimeters long fragments, where average germination reached $100 \%$ at the whole plant. Then follow 14 fragments, where germination ranges from 90 to $100 \%$ and 10 fragments with germination between 80 and $90 \%$. Clusters from all of these labeled parts had the highest dry matter values.

One of the methods, how to protect plots against weed beet infestation, is to reduce their incidence. In the second part of experiment we evaluated response of weed beets to monitored chemical substances. Number of all seed clusters at the plants in relation to selected treatment is showed in Table 2.

Number of Seed Clusters and Thousand Clusters Weight (TCW) at the Plant in Dependence on Treatment

\begin{tabular}{|l|c|c|c|c|c|c|c|}
\hline Product & Fazor 1g & Fazor 3g & Fazor 5g & Fazor 5+5g & Fazor 50g & Roundup & Control \\
\hline Number of Seeds & 2898 & 4449 & 3865 & 3890 & 331 & 5542 & 8297 \\
\hline TGW & 12,02 & 14,06 & 14,22 & 14,3 & - & 17,36 & 17,48 \\
\hline
\end{tabular}

Picture 1: Map of Weed Beet with Germination and Dry Matter Values

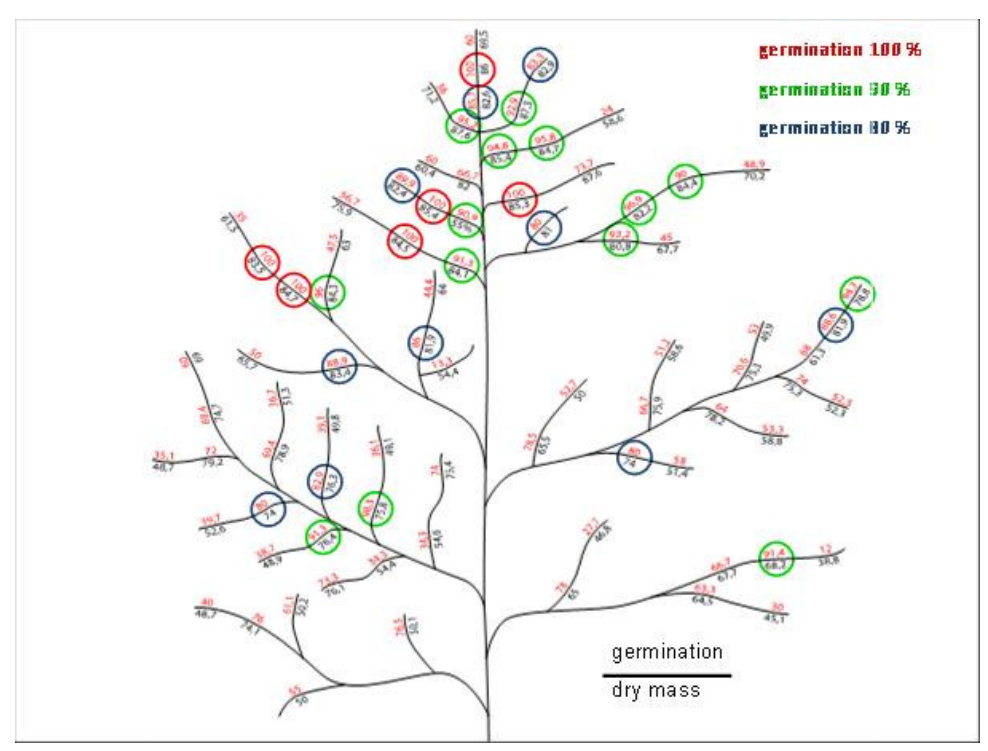


The highest amount of seed clusters at plant was in non-treated control. Our values are supported by the results of Nováková (2007), who says, that the lowest production of clusters per plant was 109, but also 10775 of clusters. With use of preparation Fazor we found significant changes in number of clusters. Nearly by half was decreased number of clusters in plants at which the preparation was applied in dose of $3 \mathrm{~g}, 5 \mathrm{~g}$ and $5+5 \mathrm{~g}$. The lowest number of seed clusters was found in the plants treated with dose of $50 \mathrm{~g}$. Average number of clusters in these variant was 331. The highest TCW was found in non-treated control plants. Its value is $17,48 \mathrm{~g}$. Jassem et al., (1997) says, that average value of TCW varies around 22,2 $\mathrm{g}$. This decrease is explained by the fact that our values are obtained from the average of 5 plants and specific values of the plants can differ significantly.

Another monitored trait was thousands glomerules weight. For better specification we divided clusters into two size fractions: $3-4 \mathrm{~mm}$ and $4.5 \mathrm{~mm}$ and more. It is generally known, that "small" clusters have worse germination and emergence, so their plot infestation is lower. On the contrary, larger, more mature clusters with higher number of reserve substances infest plots more intensively. TCW values in dependence on size fraction are in Graph 1.

Graph 1: Influence of Application of Preparations on Thousands Clusters Weight (g)

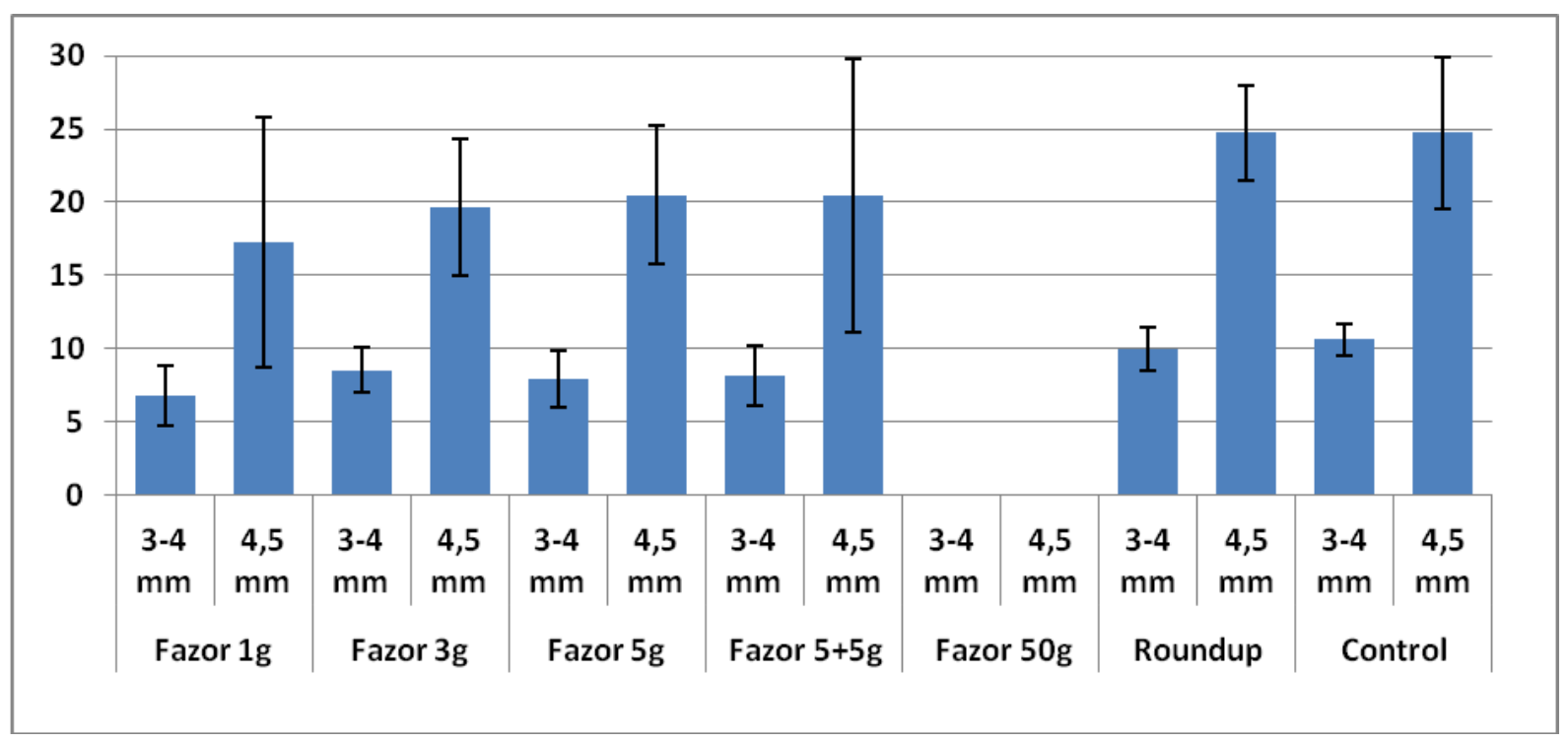

The most important seed marker is cluster germination. It was evaluated in both size categories. The lowest germination (Graph 2) was found in treatment with Fazor in dose of $50 \mathrm{~g}$, when small germination did not almost germinate and large clusters reached $7.7 \%$ germination. Other variants with use of the same preparation also did not show significant differences in germination.

Graph 2: Influence of Application of Preparations on Seed Clusters Germination (\%)

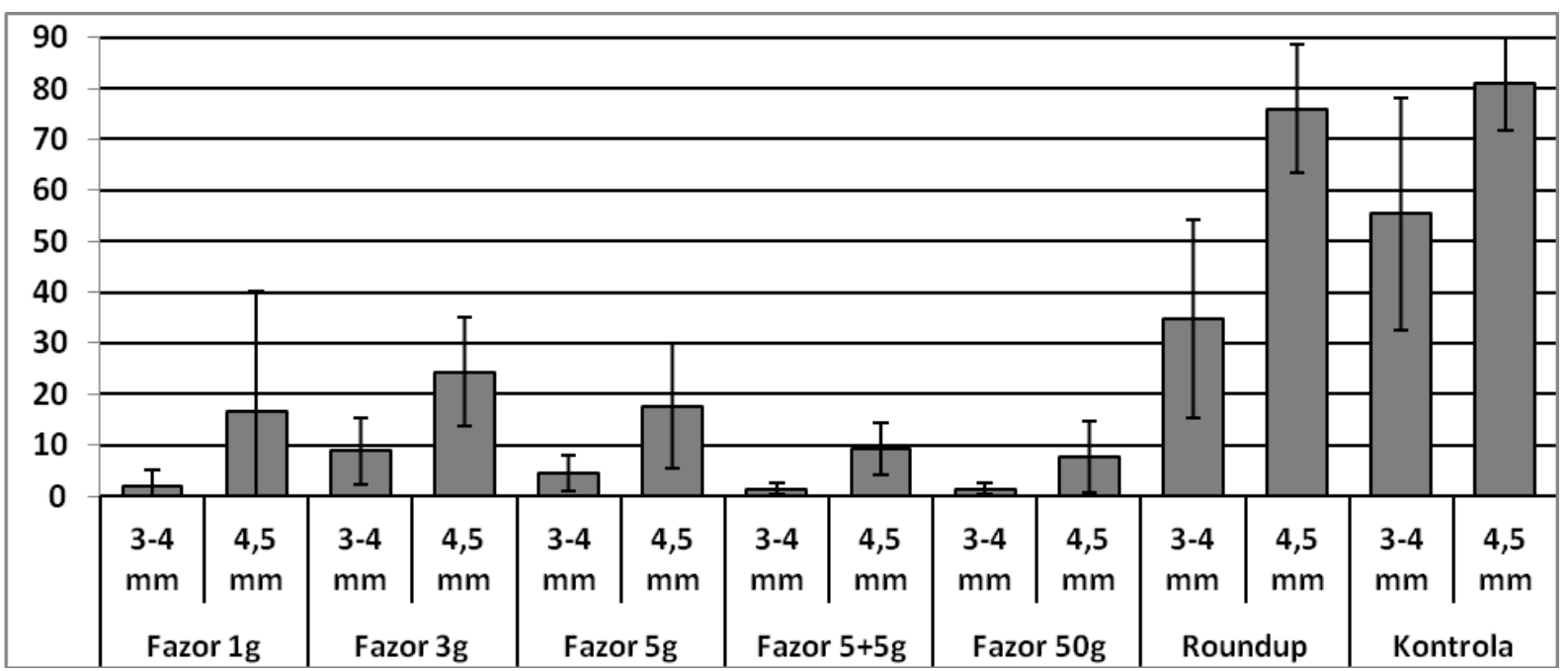


Statistically significant differences in germinability were found among control and all variants, at which was applied preparation Fazor. In this case germination of clusters in control variant had 55\% and $81 \%$, for small, respectively bigger clusters. Different situation is in clusters germination treated with Roundup. This treatment did not have significant influence on germination. Due to sclerenchymatous pericarp mature clusters keep high germination. Influence could have also application term and dose for specific plants. Similar experiments with application of Roundup on weed beet plants have also been performed by Skalický (2009), who found seed clusters germination above $4.5 \mathrm{~mm}$, affected with Roundup $56 \%$ and without Roundup $73 \%$.

\section{CONCLUSION}

Presented results are only preliminary and one-year results. Preparation Fazor with active substance maleinhydrazin influenced monitored traits: TSW, number of clusters and their germination. In all of these monitored traits these values were significantly lower in comparison with control. The lowest concentration of the preparation $-1 \mathrm{~g}$ - proved to be the best, when in the first year of testing it reached the lowest values. Germination of clusters decreased to $1.8 \%$ or $16.5 \%$. The same trend in germination and decrease of clusters number was found also in other variants. These results are one year results and we do not know how would react the plants of culture sugar beet to application of this preparation.

The plant treatment with Roundup in the phase of $\mathrm{BBCH} 82$ resulted in emergency maturation of the whole plant and did not significantly influence clusters properties and especially theirs germination. It proves that it is necessary to perform this measure in the earlier phase. Sugar beet is still a strategic plant for many enterprises and a source of finances, and so it is necessary to keep plots without weed infestation.

This article arose behind supports grant CIGA 21160/1313/3105

\section{REFERENCE}

Fišer F. (2009). Jak zvládnout další zaplevelení porostů cukrovky po první aplikaci herbicidů. Listy cukrovarnické a řepařské, 125, č. 5-6, 2009, $154 \mathrm{~s}$.

Jassem, M.-Olsezewska,D.-Dabrowaka, B. (1997) :Fenologiczna i morfologiczna charakterystyka burako chwastów. Biuletyn Intytutu Hodovli i Aklimatyzacji Roślin, 202, 1997, s. 213-219.

Jursík, M.-Holec, J.-Soukup, J.-Venclová, V. (2010): Seasonal emergence of selected summer annual weed species in dependence on soil temperature, PLANT SOIL ENVIRON., 56, 2010 (9): 444-450

Krouský, J. (2001) : Plevelná řepa, staronový nepřítel, Listy cukrovarnické a řepařské, 117, 2001, č. 9-10, s. 208210.

Nováková K. (2007): Studium biologie plevelné řepy s přihlédnutím k zavádění transgenních odrůd cukrovky, Disertační práce ČZU Praha 2007

Sester M.-Delanoy M.-Colbach N.-Darmency H. (2004). Crop and density effects on weed beet growth and reproduction. Weed Research 44 (1), 50-59.

Sester, M.-C. Dürr, C.-Darmency, H.-Colbach, N. (2006): Evolution of weed beet (Beta vulgaris L.) seed bank: quantification of seed survival, dormancy, germination and pre-emergence growth. Eur. J. Agron. 24, 19-25.

Skalický M. (2009): Stress by non-selective Herbidides: germinating capacity and structural changes in the Weed Beet plants (Beta vulgaris L.) Cereal Research Communications, VIII. Alps-Adria Scientific Workshop Neum, Bosnia-Herzegovina, 2009

Tyšer L.-Nečasová M. (2009): Současné spektrum plevelů v porostech cukrovky na vybraných plochách České republiky, Listy cukrovarnické a řepařské, 125, č. 4, 2009, $116 \mathrm{~s}$. 